\title{
The Need to Go Beyond GDP in Measuring Development
}

\author{
Eric S. M. S. Makura \\ Women"s University in Africa, Dept. of Education and Development Studies, Mt. Pleasant, Harare, Zimbabwe
}

\begin{abstract}
This ARTICLE is a Rejoinder to a Paper entitled, "AFRICAN AND ASIAN DEVELOPMENT COMPARED: LESSONS FOR ZIMBABWE”, jointly presented at the Women's University in Africa in December 2014 by Dr. Roel Van der Veen and Dr. Jan Bade. The Paper was anchored on the GDP and painted a rather gloomy picture about development in Africa. Such a depiction clearly exposes serious flaws in the use of GDP as an appropriate instrument of measuring development. The instrument is not only in capable of accurately measuring development, but equally economic growth, per capita, and quality of life. That GDP is incapable of accurately measuring these aspects of life is not the fault of its architect, Simon Kuznets, who devised it in 1934, but that of neoclassical and neo-liberal scholars, who have tended to inappropriately use the instrument. Kuznets's primary aim was for the instrument to provide Franklin Roosevelt Government with as accurate information as possible on the performance of the American formal economy that was undergoing serious shrinkage during the 1930s worldwide Great Depression.
\end{abstract}

Keywords: Development, Gross Domestic Product, Economic Growth, Economic and Social Well-Being

\section{Introduction}

This ARTICLE is a Rejoinder to a Paper entitled, "African and Asian Development Compared: Lessons For Zimbabwe", jointly presented at the Women's University in Africa on $8^{\text {th }}$ December 2014 by Dr. Roel Van der Veen and Dr. Jan Bade of The United Kingdom of The Netherlands [1]. The Paper explained the differences in development between certain African and South-East Asian countries, articulating reasons for the disparity, and suggesting certain lessons for Zimbabwe. It had an array of graphs and tables, clearly illustrating a rather gloomy picture about development in Africa. Economic growth in Africa was shown as gradually rising during the Colonial Period, but getting almost stagnant after Decolonisation, while in South-East Asia it was almost at the same level as in Africa during the Colonial Era, but sharply rising after Decolonisation. This implies that, Rusununguko/Inkululeko/Freedom Kwacha/Uhuru that was attained after a protracted struggle has not brought any meaningful improvements in the economic and social wellbeing of the Indigenes. This, does not make any sense at all, and, is indeed absurd. Economic growth in Africa might appear elusive, according to the Growth Domestic Product (GDP) upon which the Paper is anchored, but it is not at all an accurate reflection of development endeavours in the continent since Decolonisation. Such a reflection, if anything, clearly exposes serious flaws in the use of GDP as an appropriate instrument of measuring development/progress. This ARTICLE posits that, by basing their comparative analysis solely on the GDP, the two Dutch scholars failed to sufficiently understand and appreciate significant improvements in economic, social, political, cultural, moral, and ecological dimensions that have been made in Africa since Decolonisation, for economic growth, which GDP measures, is not at all the same thing as development. The former refers to an increase in the market value of formal production in a country over a year [2]. On the other hand, unlike the narrowly focused former, the latter is a multidimensional process, embracing not only an increase in formal production, but equally, that of informal production, that of underground or "off-the-books" economic activities, and that of illicit transactions, and of improvements in social, political, cultural, moral, and ecological dimensions, all of which contribute to improved quality of life for all people in society and not just a few, culminating in human happiness and increased self-esteem [3], which is the raison d' etra for any development. The ARTICLE argues that, GDP grossly undervalues economic growth, for it measures the market value of only formal production, and excludes that of not only informal production, but also that of underground economic activities, and that of illicit transactions, which all combined, are widely considered to constitute about threetimes more than the value of formal production, which is the only production GDP measures [4]. This gross underestimate, is even much higher in Developing Countries, for production in these countries is largely carried out informally [5]. The ARTICLE submits that, GDP is incapable of accurately measuring development, for development is a multi-dimensional process, embracing not only economic growth, but also improvements in social, political, cultural, moral, and ecological dimensions [6]. The ARTICLE asserts that development in Africa can only be best understood and appreciated, if both endogenous and exogenous factors are taken into account, rather than focusing on either. It emphasizes that, Africa needs to impugn the paternalistic and sonorous nothing urge by neoclassical and neo-liberal scholars, the ,apostles ${ }^{\text {ee }}$ of the openmarket economy, to emulate the North or the East and try to catch up with them. Rather, Africa should be proud of itself and vigilantly guards its abundant natural resources and what one may call ,Asian and European Buccaneer Intrusion "e, and continue focusing on human development [7], the only broad-based development paradigm that enables it to improve the economic and social well-being of all its people. Lastly, the ARTICLE contends that while „The Land of Canaan "er „The Land of Abundance ee promised by the gallant leaders of the Liberation Struggle might appear not to have been realised, indeed, may still be a long way to be achieved, one has to appreciate significant improvements in economic, social, political, cultural, moral, and ecological dimensions 


\section{International Journal of Science and Research (IJSR) \\ ISSN (Online): 2319-7064}

Index Copernicus Value (2013): 6.14 | Impact Factor (2014): 5.611

that have been made in Africa since Decolonisation, for during the Colonial Epoch, an African was nothing, but the down-trodden in every sphere of life [8] - THE WRETCHED OF THE EARTH.

\section{Origins of GDP}

The 1930s not only saw the World experiencing a sense of economic shrinkage, popularly known as the Great Depression [9], but also European countries engaging in another world-wide military confrontation - World War II (1939-1945) [10]. This led to Treasuries of both the United Kingdom (UK) and of the United States (US) to engage in metric/arithmetic methodologies in crafting national income in an attempt to determine as accurately as possible the performance of their respective economies so that appropriate policies could be adopted. Such efforts were led in the UK by Colin Clark and in the US by Wilfred King. These metric methodologies were built upon by Simon Kuznets, Head of the US National Bureau of Economic Research, when he was tasked by Franklin Roosevelt's Government to produce a report on the national income of the US [11]. Simon Kuznets [12] then architected the now world-widely used GDP, when he crafted the National Income-1932: a Report to the US Senate, which he presented to Congress in 1934. The GDP was a flow account [13], summing the economic activity of the now accepted five domestic institutional sectors, namely, financial corporations, non-financial corporations, general government, non-profit and households.

It is worthwhile and legitimate to quote in extenso, certain comments made by Simon Kuznets after presenting to the US Congress an itemised list of things measured by GDP, for they shed light on both its purpose and limits. "The boundaries of a nation in national income are still to be defined", Kuznets [14] told the US Congress, "and a number of services, in addition to those listed above, might also be considered a proper part of the national economy's end product". He [15] went on to list, inter alia, services of housewives and other members of the family", "relief and charity", " services of owned durable goods", "earnings of odds jobs", and "earnings from illegal pursuits". While Simon Kuznets had several reasons for excluding from the GDP the things he cited, his main reason deêtre was to ensure that GDP was a precise and specialised instrument designed to measure only a narrow segment of society's activity - the money/market value of goods and services formally produced, or of those produced by paid labour, or of formal production, and nothing else. Such an instrument, Kuznets rationalized, enabled the US Government to know as accurately as possible, the money value of goods and services formally produced in the country over a year and then adopt appropriate policies that would invigorate the seriously depressed economy and create more employment opportunities, thereby enhancing the purchasing power of the citizens. It is therefore germaine to argue that, Simon Kuznets, a recipient of the prestigious Nobel Prize for inventing the GDP, cannot at all be criticised for any subsequent inappropriate use of the GDP by governments, organizations, politicians, theorists and scholars [16].
The use of GDP globally as a measure of economic performance was led by the League of Nations, the predecessor of the United Nations (UN), established at Geneva in 1919 soon after World War I (1914-1918), when in 1939 it published national income statistics of countries. The instrument was further given a "Certificate of Approvale by the Bretton Woods Conference, held in July 1944 in New Hampshire by the 44 Allied Countries, when they established the International Monetary Fund (IMF) and the World Bank. Since then, these two Bretton Woods Financial Institutions have continued to use GDP as a scorecard of economic performance in determining the credit worthiness of Developing Countries, despite the fact the instrument only measures a narrow segment of society's activity - the money/market value of goods and services only produced by paid labour, or of those formally produced, or of formal production [17]. And yet, the money value of wealth created in any country does not consists of only that of goods and services produced by paid labour, but also include that of those produced by unpaid labour, that of underground/offthe-books economic activities, and that of illicit transactions, which combined, is widely considered to constitute about three times more than that of those formally produced, which GDP measures. This, is even higher in Developing Countries. The result of this absurd use of GDP as a scoreboard in ,policingee economic performance of Developing Countries by the Bretton Woods Financial Institutions, has led to the economies of African countries being condemned as sluggish, without at all appreciating that more than three quarters of production in these countries is not done formally, but informally. Human happiness and contentment, which is the ultimate goal of any meaningful development/progress, is not promoted only by formal production, but also by other multiplicity of human endeavours and available opportunities, namely, increase in informal production, increase in off-the-books economic activities, and increase in illicit transactions, and improvements in social, political, cultural, moral and ecological dimensions. Formal production only partly contributes to the economic well-being of people; for there are other various economic activities that people engage in that also contribute to their economic well-being. Neither does formal production promote the social and ecological well-being of people [18].

\section{How GDP is calculated}

As stated earlier [19], GDP is a flow account that sums the economic activity of the accepted five domestic institutional sector namely financial corporations, non - financial corporations, general government, non - profits and households. It is tallied at least annually, but often quarterly in three ways which should all yield identical figures [20].

These three ways are:

1)Production: the sum of prices of goods and services less intermediate costs of production - the value added by industry;

2)Income: The sum of income generated by domestic production of goods and services; and 


\section{International Journal of Science and Research (IJSR) \\ ISSN (Online): 2319-7064}

Index Copernicus Value (2013): 6.14 | Impact Factor (2014): 5.611

3)Expenditure: The sum of net final expenditure on goods and services, including exports minus imports. This excludes current investment in durable assets.

As explained above, whichever of the three ways of tallying income is adopted, the figure obtained should be identical to that yielded by the other two ways.

It is important to reiterate a point made earlier, that GDP measures the market value of goods and services only formally produced, and excludes not only of those that are informally produced, but also those of underground activities, and of illicit transactions, which combined, are widely considered to constitute about three times more than those of formal production, which GDP measures. Again, as has been stated earlier, this is even higher in Developing Countries. Equally important to note, is the point that GDP is not calculated by taking surveys of the whole economy and calculating actual market value of goods and services produced by each firm. That would be impossible. The practice is that of approximating, Thus, GDP needs to be seen as nothing, but an approximation of the economic performance of a country. Indeed, Oscar Morgenstern [21], former Professor of Economics at Harvard University, has dismissed the whole process of GDP as "Garbage - In Garbage- out (GIGO) process". While Greig, Hulme and Turner [22] have similarly thrashed it as like "flying an aircraft using only the speedometer". The extent, to which GDP is divorced from reality, cannot be more underlined.

\section{The Inadequacy of GDP in Measuring Development}

Development, of which the better term is progress, is a multidimensional process, embracing not only increase in formal production in a country over a year, which is the only production GDP measures, but also of informal production, of underground/"off-the-books" economic activities, and of illicit transactions, and improvements in social, political, cultural, moral and ecological dimensions [23]. Thus, development, unlike economic growth, which GDP measures, has necessarily to be multi-dimensional, for it has to address the ever changing multiplicity of needs, aspirations and values of all the people in society, which is its main raison d'être. This underlines the inadequacy of GDP in accurately measuring development, for it measures the market value of only formal production, which is a very narrow segment of society's endeavors in trying to improve the quality of life. Thus, GDP is simply incapable of accurately measuring development, not only because it grossly undervalues economic growth, but equally because it hardly can measure improvements in social, political, cultural, moral, and ecological dimensions.

The Inadequacy of GDP in Measuring Economic Growth Thirlwall [24] states that, economic growth is the increase in output of goods and services produced in a country, usually over a year. In determining the value of such created wealth, GDP measures the market value of only formal production. It excludes the market value of not only formal production, but equally that of underground/off-the-books economic activities, and that of illicit transactions, which combined, is widely considered to constitute about three times more than that of formal production, which GDP measures. This is even much higher for Developing Countries, for their production is largely conducted informally [25]. Thus, it is cogent to argue that, GDP grossly undervalues economic growth it tries to determine. This is more so for economic growth of Developing Countries, for their production is largely informally conducted, which GDP does not measure [26]. It is high time that neo-classical and neo-liberal scholars, the IMF and the World Bank, the chief exponents of GDP, seriously realise the absurdity of continuing using this inappropriate instrument as a scorecard of economic performance. Economic performance of Developing Countries, particularly which of African countries, is not that sluggish as the proponents of GDP portray it. Economic endeavors of any society are not just confined to formal production, but include all possible opportunities that can be seized and exploited for the improvement of one,s life. Here, lies, the huge advantage of Africa over both the North and the East, which Africa is urged to emulate and try to catch up with by neo-classical and neo-liberal scholars, for it has abundant natural resources, which its people largely informally exploit for their betterment. Indeed, both the North and the East envy Africa for this. This is precisely why people from both the North and the East stampede coming to Africa.

\section{The Inadequacy of GDP in Measuring Per Capita}

Per capita is a Latin expression for income per person. It is obtained by dividing the market value of all goods and services produced in a country over a year by the population of that country [27]. However, as explained earlier [28], it is not true at all that GDP measures the market value of all the goods and services produced in a country over a year. This is a fallacy. The reality is that it measures the money value of only formal production, and nothing more. Consequently, GDP grossly undervalues economic growth, for it does not measure the money value of not only informal production, but also of underground economic activities, and of illicit transactions, which combined, is widely considered to constitute about three times more than that of formal production, which GDP measures. Again, as stated earlier, this is even much more for Developing Countries, for their production is largely done informally. Thus, per capita obtained from such a grossly undervalued GDP is clearly undervalued. On this score, GDP is incapable of accurately measuring per capita of a country.

\section{The Inadequacy of GDP in Measuring Quality of Life}

Economic growth, which GDP determines through measuring the market value of formal production in a country over a year, is firmly considered by neo-classical and neo-liberal scholars as the harbinger for improved quality of life [29]. "As a rule," Rapley [30] asserts, "there is a correlation between national income and a country"s ability to improve the social indicators of its citizenry." In an Article entitled, 


\section{International Journal of Science and Research (IJSR) \\ ISSN (Online): 2319-7064}

Index Copernicus Value (2013): 6.14 | Impact Factor (2014): 5.611

„The Poor and The Rich"e, The Economist, in Georgis Secondi [31], states:

Understanding Growth is surely the most urgent task in economics. Across the world, poverty remains the single greatest cause of misery; and the surest remedy for poverty is economic growth.

Angela Merkel [32], the German Chancellor, holds the same view: "Without growth, everything is nothing." Thus, Economic growth is seen as a fulcrum for improved quality of life.

Before showing the absurdity of equating economic growth with improved quality of life, it is worthwhile and legitimate to try and hazard definition of the quality of life. According to the World Health Organisation (WHO) [33]:

Quality of life is defined as an individual's perceptions of their position in life in the contest of the culture and value system where they live, and in relation to their goals, expectations, standards and concerns. It is a broad ranging concept, incorporating in a complex way a person es physical health, psychological state, and level of independence, social relationship, personal beliefs and relationship to salient features of the environment.

The definition clearly shows how absurd it is, to consider economic growth as the pivot for improved quality of life, for quality of life, also known as the human well-being, is an inclusive condition, embracing not only economic wellbeing, but also social well-being as well as ecological wellbeing. This, is what Aristotle $(384-322 \mathrm{BC})$, that great Athenian Philosopher, referred to as "the human good" [34], or "flourishing lives" [35]. He made it very clear that, „wealth is evidently not the good we are seeking, for it is merely useful and for the sake of something else." Aristotle s conception of the quality of life, was echoed by later Great Thinkers, inter alia, Immanuel Kant (1724 - 1804) [36], Adam Smith (1723 - 1790) [37], Robert Malthus (1766 1834) [38], Karl Marx (1818 -1883) [39], and John Stuart Mill (1806 -1873) [40].

In one of his memorable speeches, delivered at the University of Kansas on $18^{\text {th }}$ March 1968, Robert Fitzgerald Kennedy, who had served as Attorney General from 1961 to 1963 in the Democratic Government of his elder brother, President John F. Kennedy, a Pan-Internationalist, displayed the typical Irish American wit, for which the Kennedys were reputed, when he savaged the use of GDP as a measure of development. The speech [41], needs to be quoted in extenso, for it sheds light of illumination on the incapability of GDP in determining the quality of life, which Aristotle calls "the human good":

Our Gross National [Domestic] Product ... counts air pollution and cigarette advertising, and ambulances to clear our highways of carnage ... Yet the Gross National [Domestic] Product does not allow for the health of our children, the quality of their education or the joy of their play. It does not include the beauty of our poetry or the strength of our marriages, the intelligence of our public debate or integrity of our public officials. It measures neither our wit nor our courage, neither our wisdom nor our learning, neither our compassion nor our devotion to our country, it measures everything, in short, except that which makes life worthwhile. And it can tell everything about America, except why we are proud that we are Americans.

Robert Kennedy's scathing attack against the naive belief that economic growth is the core for improved quality of life, was echoed almost thirty years later by Tony Blair [42], the British Prime Minister, in a Forward to the UK Government 1990: Report on Better Quality of Life, when he admitted that:

We have failed to see how our economy, our environment and our society are all one. And that delivering the best possible quality of life for us means more than concentrating solely on economic growth.

The above citations cannot more than ridicule the decadesold and world-wide putative assumption that, economic growth is the harbinger for improved quality of life.

\section{Conclusions}

From the above discussion, certain salient points may be made. GDP is incapable of accurately measuring development for it is narrowly focused, since it measures only formal production, and excludes not only informal production, but equally underground economic activities, and illicit transactions, and improvements in the social, political, cultural, moral, and ecological dimensions, all of which contribute to improvements in the quality of life, which is raison d'etra for any development. Hence, development is a multi-dimensional process. While GDP tries to determine economic growth, it grossly underestimates such economic growth for it only measures formal production, and excludes informal production. Such underestimate is even higher for Developing Countries, for their production is largely informally conducted. Since GDP grossly undervalues economic growth, it means that per capita obtained from such a measure is also a gross undervalue. Similarly, GDP is incapable of accurately measuring quality of life, partly because, it grossly undervalues per capita, and partly because it can hardly measure improvements in social, political, cultural, moral, and ecological dimensions, all of which contribute to improvements in the quality of life. Perhaps, Stefan Bergheim [43] could not have made a more scathing attack against the world-wide ubiquitous tendency of using GDP as a handmaiden for improved quality of life, when he commented that, "All too often, GDP is interpreted as a measure of welfare - well-being - which it is not and was never designed to be." 


\section{International Journal of Science and Research (IJSR) \\ ISSN (Online): 2319-7064}

Index Copernicus Value (2013): 6.14 | Impact Factor (2014): 5.611

\section{Notes}

[1] The Author was a Panelist when the Paper was presented as a Public Lecture at the Women's University in Africa in December 2014, and strongly disputed the premise, findings, and conclusions of the Paper. He had intended this Rejoinder to be published in a Journal the Women's University in Africa had planned to launch in 2015, but has so far not done so.

[2] See Samuelson, P.A. and W. D. Nordhaus (1985): Economics, New York, McGraw Hill Press., Kulkarni, K.G. (2008): Principles of Macro - Monetary Economics, Kendall/Hunt Publishing., Edwards, G. (2006): „Political Arithmetick: Problems With GDP as Economic Progress ${ }^{e e}$, In Deutsche Bank Research.

[3] See Max-Neef, M. (1995): ,Economic Growth and Quality of Life: A Threshold Hypothesisee, Ecological Economics 15 (2): 115 - 118., Inglebait, R. (1997): Modernisation and Post Modernisation: Cultural, Economic, and Political Change in 43 Societies, Princeton University Press., Edwards, G. (2006): Op. Cit., Thirlwall, A.P.C. (2006): Growth and Development: With Special Reference to Developing Economies, London, MacMillan Press., Bergheim, S. (2006): Measures of well-being: There is more to it than GDP, Deutsche Bank Research; Hamilton, K., G.Ruta et al. (2006): Where is the Wealth of Nations? Measuring Capital for the $21^{\text {st }}$ Century, Washington, DC; The World Bank, Environment Commission. (2007): Summary notes from the Beyond GDP Conference: Highlights from the Presentations and the Discussion. Beyond GDP: Measuring Progress, True Wealth, and the Well-Being of Nations, Brussels: European Commission; Goessens, Y., A. Makipaa et al. (2007): Alternative Progress Indicators to Gross Domestic Product (GDP) as a Means Towards Sustainable Development, Brussels, European Parliament, Policy Department A: Economic and Scientific Policy; Commission on Growth and Development (2008): The Growth Report: Strategies for Sustained Growth and Inclusive Development, Washington, DC, World Bank., Kulkarni, K.G. (2008): Op. Cit.; Rapley, J. (2008): Understanding Development: Theory and Practice in the Third World, Lynne Rienner Publishers, New York., Costanza, R., M. Hart, S. Posner, J. Talberth. (2009): Beyond GDP: The Need for New Measures of Progress, The Frederick S. Pardee.

[4] Ibid.

[5] See Hamilton, K., G.Ruta et al. (2006): Op. Cit., Goessens, Y., A. Makipaa et al. (2007): Op. Cit., England, R.W.C. (1998): Measurement of Social WellBeing: Alternatives to Gross Domestic Product, Ecological Economics, 25: 89 - 103.; Costanza, R., M. Hart, S. Posner, J. Talberth. (2009): Op. Cit., Daly, H. E., and J.B. Cobb, Jnr. (1989): For the Common Good: Redirecting the Economy Toward Community, the Environment, and a Sustainable Future, Boston, Beacon Press., Kulkarni, K.G. (2008): Op. Cit., Rapley, J. (2008): Op. Cit.

[6] See Bergheim, S. (2006): Op. Cit., Hamilton, K., G. Ruta et al. (2006): Op. Cit., Environment Commission.
(2007): Op. Cit., Goessens, Y., A. Makipaa et al. (2007): Op. Cit., Kulkarni, K.G. (2008): Op. Cit., Costanza, R., M. Hart, S. Posner, J. Talberth. (2009): Op. Cit.

[7] See Hag, M.U. (2008): „The Human Development Paradigm 'e, In Secondi, Giorgie (ed.) (2008): The Development Economics Reader, London, Routledge Press.

[8] For a detailed analysis on rabid racist colonial domination and exploitation, see Eric S.M.S. Makura: Southern Rhodesia: The Making and Implementation of the Two-Pyramid Policy, 1890 - 1948: A Study in Discrimination and Exploitation, Ph.D. Thesis, Dalhousie University Centre of African Studies, Halifax, Nova Scotia, Canada, 1982.

[9] See Samuelson, P.A. and W. D. Nordhaus (1985): Economics, New York, McGraw Hill Press.

[10] See Wilson, H.S. (1977): The Imperial Experience in Sub-Saharan Africa Since 1870, Minneapolis, University of Minnesota Press.

[11] See Marcus, R.D. and Kane, R.E. (2007): US National Income and Product Statistics: Born of the Great Depression and World War II Bureau of Economic Analysis: Survey of Current Business 87 (2): pp. 32 46.

[12] See Kuznets, S. (1934): National Income 1929 - 1932: A Report to the U.S.A. Senate, $73^{\text {rd }}$ Congress, $2^{\text {nd }}$ Session, Washington, D.C, US Govt. Printing Office.

[13] See Philipsen, D. (2015): The Little Big Number: How GDP Came To Rule the World and What to Do About It, Princeton, Princeton University.

[14] Kuznets, S. (1934): Op. Cit. p. 3

[15] Ibid.: pp. 3 -5

[16] See Bergheim, S. (2006): Op. Cit., Environment Commission. (2007): Op. Cit., Goessens, Y., A. Makipaa et al. (2007): Op. Cit., Kulkarni, K.G. (2008): Op. Cit., Costanza, R., M. Hart, S. Posner, J. Talberth. (2009): Op. Cit.

[17] Costanza, R. et al. (2009): Beyond GDP, pp. 5 - 6 .

[18] See McCulla, S.H. and S. Smith. (2007). Measuring the Economy: A Primer on GDP and the National Income and Product Accounts, Washington, DC, Bureau of Economic Analyses: US Dept. of Commerce; Costanza, R. et al. (2009): Beyond GDP, 6 - 7., Kulkarni, K.G. (2008): Op. Cit., Bergheim, S. (2006): Op. Cit., Boarini, R., A. Johansson and M. Mira deErcole (2006): Alternative measures of well -being, OECD Social Employment and migration working papers No. 33., Kahneman, D, A. B. Krueger, D. Schkade, N. Schwarz and A. Stone (2004): Toward National Being Accounts, American Economic Review 94 (2) Papers and Proceedings, pp. 429 - 434., Layard, R. (2006): Happiness and Public Policy: A Challenge to the Profession, Economic Journal 116, pp. C24 - C33.

[19] See Foot Note 2

[20] See Edwards, G. (2006): Op. Cit.

[21] See Morgenstern, O. (1963): On the Accuracy of Economic Observations, Princeton University Press.

[22] See Greig, A., D. Hulme, and M, Turner. (2007): Challenging Global Inequality: Development Theory and Practice in the $21^{\text {st }}$ Century, London, Palgrave MacMillan, 37. 


\section{International Journal of Science and Research (IJSR) \\ ISSN (Online): 2319-7064}

Index Copernicus Value (2013): 6.14 | Impact Factor (2014): 5.611

[23] See Goulet, D. (1971): The Cruel Choice: A New Concept in the Theory of Development, New York, Athenaeum., Thirlwall, A.P.C. (2006): Op. Cit., Kulkarni, K.G. (2008): Op. Cit., Costanza, R., M. Hart, S. Posner, J. Talberth. (2009): Op. Cit., Edwards, G. (2006): Op. Cit., Kothari, U. And Minogue (eds.) (2002): Development Theory and Practice: Critical Perspectives, Basingstoke, Palgrave Press., McCulla, S. and S. Smith (2007): Op. Cit., Environment Commission (2007): Op. Cit., Commission on Growth and Development (2008): Op. Cit., Thirlwall, A.P.C. (2006): Op. Cit.

[24] See Thirlwall, A.P.C. (2006): Op. Cit.

[25] See Hamilton, K., G. Ruta, et al. (2006): Op. Cit., Goossens, Y., A. Makipaa, et al. (2007): Op. Cit., McCulla, S. and S. Smith (2007): Op. Cit., Kulkarni, K.G. (2008): Op. Cit., McKibbeenm, B. (2007): Deep Economy, The Wealth of Communities and the Durable Future, New York, Times Books., Talberth, J.C. (2008): A New Bottom Line for Progress: 2008 State of the World: Innovations for a Sustainable Economy, New York, W.W. Norton \& Company.

[26] See Thirlwall, A.P.C. (2006): Op. Cit., Inglebait, R. (1997): Op. Cit., Hamilton, K., G.Ruta et al. (2006): Op. Cit., Costanza, R., M. Hart, S. Posner, J. Talberth. (2009): Op. Cit.

[27] See Samuelson, P.A. and W. D. Nordhaus (1985): Op. Cit., Kulkarni, K.G. (2008): Op. Cit.

[28] See Foot Note 2

[29] See Helpman, E. (2004): The Mystery of Economic Growth, Cambridge, Massachusetts, Harvard University Press.

[30] Rapley, J. (2008): Op. Cit., p. 10

[31] Secondi, Georgis (ed.) (2008): Op. Cit., p. 42

[32] Angela Merkel, in Costanza, R., M. Hart, S. Posner, J. Talberth. (2009): Op. Cit., p. 3

[33] World Health Organization (1993): World Development Report 1993: Investing in Health, New York, Oxford University Press, pp. 12 -13.

[34] See Kraut, R. (1991): Aristotle on the Human Good, Princeton, Princeton University Press.

[35] Ibid.

[36] See Jennings, B. (2002): Quality of Life, Philosophical and Ethical Dimensions, The Gale Group Inc., Sullivan, R.J (1989): Immanuel Kant's Moral Theory, London, Cambridge University Press.

[37] See Smith, Adam (1776): An Inquiry into the Nature and Causes of the Wealth of Nations, London, W. Strahan and T. Cadell.

[38] See Malthus, Robert Thomas (1798): An Essayb on the Principle of Population, London, J. Johnson.

[39] Jennings, B. (2002): Op. Cit.

[40] Ibid.

[41] Robert Kennedy's Speech on 18 March, in The New York Times of 19 March, 1968.

[42] Forward by British Prime Minister Tony Blair, in United Kingdom Government (1990): Report on Better Quality of Life, London, HM Printers.

[43] See Begheim, S. (2006): Op. Cit., p. 4.

\section{References}

[1] Bergheim, S.: Measures of well-being: There is more to it than GDP, Deutsche Bank Research, 2006.

[2] Boarini, R., A. Johansson and M. Mira d'Ercole: Alternative measures of well -being, OECD Social Employment and migration working papers No. 33, 2006.

[3] Commission on Growth and Development: The Growth Report: Strategies for Sustained Growth and Inclusive Development, Washington, DC, World Bank, 2008.

[4] Costanza, R., M. Hart, S. Posner, J. Talberth. : Beyond GDP: The Need for New Measures of Progress, The Frederick S. Pardee, 2009.

[5] Daly, H. E., and J.B. Cobb, Jnr. : For the Common Good: Redirecting the Economy Toward Community, the Environment, and a Sustainable Future, Boston, Beacon Press, 1989.

[6] Edwards, G.: „Political Arithmetick: Problems With GDP as Economic Progresse, In Deutsche Bank Research, 2006.

[7] England, R.W.C.: „Measurement of Social Well-Being: Alternatives to Gross Domestic Productee, Ecological Economics, 25: 1998.

[8] Forward by British Prime Minister Tony Blair, in United Kingdom Government: Report on Better Quality of Life, London, HM Printers, 1990.

[9] Goessens, Y., A. Makipaa et al.: Alternative Progress Indicators to Gross Domestic Product (GDP) as a Means Towards Sustainable Development, Brussels, European Parliament, Policy Department A: Economic and Scientific Policy, 2007.

[10] Goulet, D.: The Cruel Choice: A New Concept in the Theory of Development, New York, Athenaeum, 1971.

[11] Greig, A., D. Hulme, and M, Turner. (2007): Challenging Global Inequality: Development Theory and Practice in the $21^{\text {st }}$ Century, London, Palgrave MacMillan, 2007.

[12]Hag, M.U.: „The Human Development Paradigme, In Secondi, Giorgie (ed.): The Development Economics Reader, London, Routledge Press, 2008.

[13]Hamilton, K., G.Ruta et al.: Where is the Wealth of Nations? Measuring Capital for the $21^{\text {st }}$ Century, Washington, DC, 2006.

[14]Helpman, E.: The Mystery of Economic Growth, Cambridge, Massachusetts, Harvard University Press, 2004.

[15] Inglebait, R.: Modernisation and Post Modernisation: Cultural, Economic, and Political Change in 43 Societies, Princeton University Press, 1997.

[16] Jennings, B.: Quality of Life, Philosophical and Ethical Dimensions, The Gale Group Inc, 2002.

[17] Kahneman, D, A. B. Krueger, D. Schkade, N. Schwarz and A. Stone: „Toward National Being Accounts"e American Economic Review 94 (2), 2004.

[18] Kothari, U. And Minogue (eds.) : Development Theory and Practice, 2002.

[19] Kraut, R.: Aristotle on the Human Good, Princeton, Princeton University Press, 1991.

[20] Kulkarni, K.G.; Principles of Macro - Monetary Economics, Kendall/Hunt Publishing, 2008. 


\section{International Journal of Science and Research (IJSR) \\ ISSN (Online): 2319-7064}

Index Copernicus Value (2013): 6.14 | Impact Factor (2014): 5.611

[21] Kuznets, S.: National Income 1929 - 1932: A Report to the U.S.A. Senate, $73^{\text {rd }}$ Congress, $2^{\text {nd }}$ Session, Washington, D.C, US Govt. Printing Office, 1934.

[22] Layard, R.: Happiness and Public Policy: „A Challenge to the Profession"e, Economic Journal 116, 2006.

[23] Malthus, Robert Thomas: An Essay on the Principle of Population, London, J. Johnson, 1798.

[24] Marcus, R.D. and Kane, R.E.: „US National Income and Product Statistics: Born of the Great Depression and World War II', Bureau of Economic Analysis: Survey of Current Business 87 (2), 2007.

[25] Max-Neef, M. ,Economic Growth and Quality of Life: A Threshold Hypothesisee, Ecological Economics 15 (2), 1995.

[26] McCulla, S.H. and S. Smith. : Measuring the Economy: A Primer on GDP and the National Income and Product Accounts, Washington, DC, Bureau of Economic Analyses: US Dept. of Commerce, 2007.

[27] McKibbeenm, B.: Deep Economy, The Wealth of Communities and the Durable Future, New York, Times Books, 2007.

[28] Morgenstern, O.: On the Accuracy of Economic Observations, Princeton University Press, 1963.

[29] Philipsen, D. : The Little Big Number: How GDP Came To Rule the World and What to Do About It, Princeton, Princeton University, 2015.

[30] Rapley, J.: Understanding Development: Theory and Practice in the Third World, Lynne Rienner Publishers, New York, 2008.

[31] Robert Kennedy's Speech on 18 March, in The New York Times of 19 March, 1968.

[32] Samuelson, P.A. and W. D. Nordhaus: Economics, New York, McGraw Hill Press, 1985.

[33] Secondi, Georgis (ed.): Development Economics Reader, 2008.

[34] Smith, Adam: An Inquiry into the Nature and Causes of the Wealth of Nations, London, W. Strahan and T. Cadell, 1776.

[35] Sullivan, R.J: Immanuel Kant's Moral Theory, London, Cambridge University Press, 1989.

[36] Talberth, J.C.: A New Bottom Line for Progress: 2008 State of the World: Innovations for a Sustainable Economy, New York, W.W. Norton \& Company, 2008.

[37] The World Bank, Environment Commission.: Summary notes from the Beyond GDP Conference: Highlights from the Presentations and the Discussion. Beyond GDP: Measuring Progress, True Wealth, and the WellBeing of Nations, Brussels: European Commission, 2007.

[38] Thirlwall, A.P.C.: Growth and Development: With Special Reference to Developing Economies, London, MacMillan Press, 2006.

[39] Wilson, H.S.: The Imperial Experience in Sub-Saharan Africa Since 1870, Minneapolis, University of Minnesota Press, 1977.

[40] World Health Organization: World Development Report 1993: Investing in Health, New York, Oxford University Press, 1993.

\section{Author Profile}

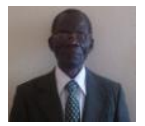

Eric S.M.S. Makura is an Ex-Detainee and Political Prisoner, incarcerated at Hwa Hwa Detention Centre (1966 - 1968) by the Rhodesian Regime of Ian Smith for Political Activism. He read for the Master of Philosophy (M.Phil.) (1978) and the Doctor of Philosophy (Ph.D.) $(1979$ - 1982) in Economic History, both at Dalhousie University Centre for African Studies (DUCAS), Halifax, Nova Scotia, Canada, as a Canadian International Development Agency (CIDA) Fellow, the same Fellowship of which he held at the University of Manitoba, Winnipeg, where he read for the Master of Arts (M.A.) (1977 - 1978) in Economic History. He did the Bachelor of Arts Honours. (B.A. Hons.) (1974 - 1977) in History and Economics at the University of York, Yorkshire, England, as a Commonwealth Scholar. After his return from exile, he did the Post - Graduate Diploma in Education (P.G.D.E.) (1990) at the University of Zimbabwe, Mount Pleasant, Harare. His Doctoral Thesis is entitled: Southern Rhodesia: The Making and Implementation of the Two-Pyramid Policy, 1890 - 1948: A Study in Discrimination and Exploitation (513 pages). He has held Lectureships at various Universities both overseas and in Zimbabwe. Currently, he is Head of Development Studies at Women"s University in Africa (WUA), and Advisor of WUA Alumni, Harare, Zimbabwe. 